\title{
Photo-lithological map of the southern flank of the Tindouf Basin (Western Sahara)
}

\section{Andrea Ciampalini , Francesca Garfagnoli , Benedetta Antonielli, Chiara Del Ventisette \& Sandro Moretti}

To cite this article: Andrea Ciampalini , Francesca Garfagnoli , Benedetta Antonielli , Chiara Del Ventisette \& Sandro Moretti (2012) Photo-lithological map of the southern flank of the Tindouf Basin (Western Sahara), Journal of Maps, 8:4, 453-464, DOI: 10.1080/17445647.2012.746947

To link to this article: https://doi.org/10.1080/17445647.2012.746947
(2) Copyright Andrea Ciampalini, Francesca
Garfagnoli, Benedetta Antonielli, Chiara Del Ventisette and Sandro Moretti

\section{+ View supplementary material ¿}

\section{Published online: 26 Nov 2012.}

Submit your article to this journal $\llbracket$

Џll Article views: 425

Q View related articles

Citing articles: 13 View citing articles 


\title{
SCIENCE
}

\section{Photo-lithological map of the southern flank of the Tindouf Basin (Western Sahara)}

\author{
Andrea Ciampalini*, Francesca Garfagnoli, Benedetta Antonielli, Chiara Del Ventisette and Sandro Moretti
}

Department of Earth Sciences, University of Firenze, Firenze, Italy

(Received 30 May 2012; Resubmitted 30 October 2012; Accepted 2 November 2012)

\begin{abstract}
This paper examines the potential to map surface geology by applying specific enhancement techniques to Landsat 7 ETM + imagery, resulting in false color composite images, which were interpreted and then validated during a field campaign. The study area is located on the southern flank of the Tindouf Basin (Western Sahara), and it is noted that there is a general lack of bibliographic data due both to the region's remote location and to its difficult political situation. A number of photo-lithological units were mapped within the Proterozoic basement and the sedimentary succession of the Tindouf Basin incisively contributing to the knowledge of the geological setting of this area.
\end{abstract}

Keywords: Landsat ETM +; enhancement techniques; photo-interpretation; geological mapping; Tindouf Basin; Western Sahara

\section{Introduction}

Landsat images have proved to be an inexpensive and useful tool in the discrimination of lithologies, characterized by different spectral properties (Deller, 2006; Gupta, 2003; Wulder et al., 2008; Zumsprekel \& Prinz, 2000). They are an effective, time and cost-saving method for geological mapping of large areas, and it is especially useful in areas difficult to reach to carry out traditional geological surveys. A suitable analysis of satellite optical images, such as Landsat 7 ETM +, substantially helps in lithological investigation of poorly understood areas. This is particularly true in arid environments, where the lack of both vegetation cover and thick soils allows a clear observation of the outcropping rock sequences (Baghdadi, Grandjean, Lahondére, Paillou, \& Lasne 2005; Dawelbait \& Morari, 2011; Gad \& Kusky, 2006). In this study, Landsat 7 ETM+ images were analyzed using specific enhancement techniques, such as band ratios, color composites and principal component analysis (PCA) (Dehnavi et al., 2010; Dogan, 2008, 2009; Kaufmann 1988; Madani, 2009; Rajesh, 2008; Sabins, 1999; Shalaby, Bishta, Roz, \& Zalaky, 2010). Using enhancement techniques, different photo-lithologic units on the southern flank of the Tindouf Basin (Western Sahara) were mapped through visual interpretation, validated with ground-truth data, and compiled using a geographic information system (GIS). The study area is located in the SADR (Saharawi Arab Democratic Republic) territory, which is bounded to the south and east by the Mauritania border and to the north and west by the Moroccan wall (Figure 1). Few studies concerning the southern flank of the Tindouf Basin have been published (Guerrak, 1988a, 1988b, Guerrak, 1991; Villeneuve, 2005). This lack of geological data could be explained by the remote location and to the recent political situation. Photo-interpretation of Landsat 7 ETM+ images was performed for a test area of about $9400 \mathrm{~km}^{2}$. This paper contributes to the knowledge of the geological setting of an area that has not been mapped in detail yet, and substantiates the use of remote sensing methods as a proxy geologic mapping technique. The information about the geology of another part of the Tindouf basin (Djebilet, Algeria), characterized by the same sedimentary sequence and rocks, combined to the remote sensing techniques were used to extend the geological interpretation to the study area. The obtained photo-lithological map was validated through a field investigation where the lithologies were verified.

*Corresponding author. Email: andrea.ciampalini@unifi.it

ISSN 1744-5647 online

(C) 2012 Andrea Ciampalini, Francesca Garfagnoli, Benedetta Antonielli, Chiara Del Ventisette and Sandro Moretti http://dx.doi.org/10.1080/17445647.2012.746947

http://www.tandfonline.com 


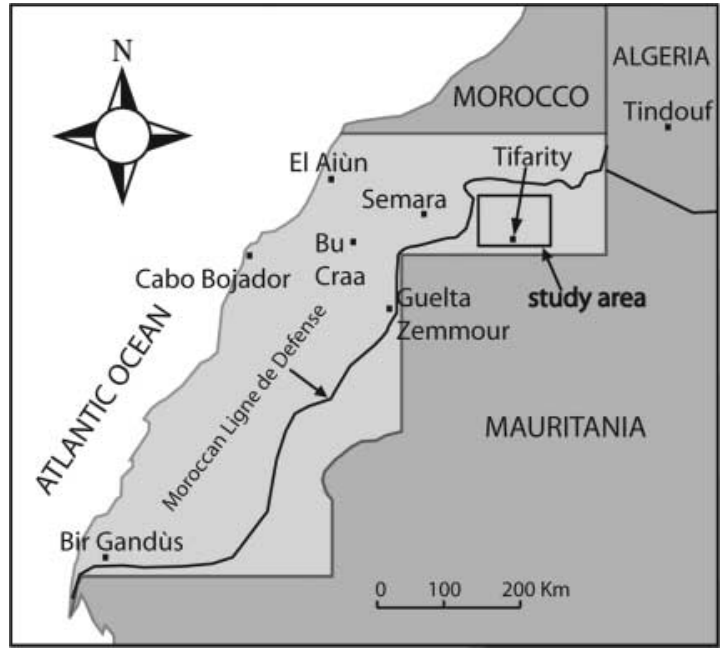

Figure 1. Location map of the study area.

\section{Geological setting}

The study area is a part of the SADR territory, located in Western Sahara (Figure 1), where both the Precambrian basement (Reguibat Shield) and the Paleozoic sedimentary rocks of the Tindouf Basin crop out (Figure 2). The area, situated along the southern boundary of the Tindouf Basin, was not affected by Paleozoic tectonic movements, nor by any later deformation (Schindler \& Wehrmann, 2010).

\subsection{The Reguibat Shield}

The Reguibat Shield, consists of Archean rocks (3.5 Ga) to the west and latest Proterozoic units to the east (Peucat, Capdevila, Drareni, Mahdjoub, \& Kahoui, 2005) and it is bounded by the Proterozoic to Paleozoic Taoudeni Basin to the south (Barth, Rudnick, Carlson, Horn, \& McDonough, 2002) and by the Tindouf Basin to the north. The Reguibat Shield consists of syenite, granite and subordinately gabbro (Figure 2).

\subsection{The Tindouf Basin}

The Tindouf Basin is limited to the northeast by the Hercynian Ougarta Belt, to the west by the Dhlou Belt, which is part of the Hercynian Mauritanide Belt, and to the south by the Reguibat Shield (Villeneuve, 2005). The Tindouf Basin forms an elongated WSW-ENE trending $(800 \mathrm{~km})$ asymmetrical syneclise, evolved from cratonic sedimentation on the Saharan Platform. The two flanks of the basin are well exposed, whereas the central part is covered by so-called Hamadian formations, formed by Cretaceous, Tertiary and Quaternary sedimentary units (Allek \& Hamoudi, 2008; Deynoux, Affato, Trompette, \& Villeneuve, 2006; Villeneuve, 2005). The Paleozoic sedimentary sequence in the Tindouf Basin is well exposed in the Anti-Atlas area, where it was partially involved in PanAfrican orogenic deformations (Lubeseder, Redfern, \& Boutib, 2009). Here the gently dipping $\left(1^{\circ}-5^{\circ}\right)$ southern flank wedges out southwards onlapping on the Reguibat Shield (Deynoux et al., 2006). Specifically, the deposition of Paleozoic sediments on the northern margin of the Saharan craton evolved as follows (Lubeseder et al., 2009): during the Late Ordovician, periglacial and marine sandstones covered large parts of North Africa (Ghienne, 2003; Le Heron, 2007; Loi et al., 2010). A post-glacial Early Silurian transgression shifted the shoreline far southwards, leading to widespread graptolite-shale deposition. During the Early Devonian a major regression allowed the progradation of several deltaic system (Lubeseder et al., 2009) over the Silurian graptolite-shale succession (Destombes, Hollard, \& Willefert, 1985). During the Middle Devonian, siliciclastic supply was largely cut over much of northwestern Africa, leading to widespread carbonate deposition. The Late Devonian was again dominated by shale deposition, until a marked Late Famennian sea-level fall allowed a rapid progradation of deltaic sandstones (Lubeseder et al., 2009). Although the aforementioned stratigraphic sequence, described by Guerrak (1988a), crops out along the southern flank of the Tindouf Basin, close to Djebilet (Algeria), about $300 \mathrm{~km}$ eastward of the study area, it has been taken into consideration because of its similarity to those cropping out in the 


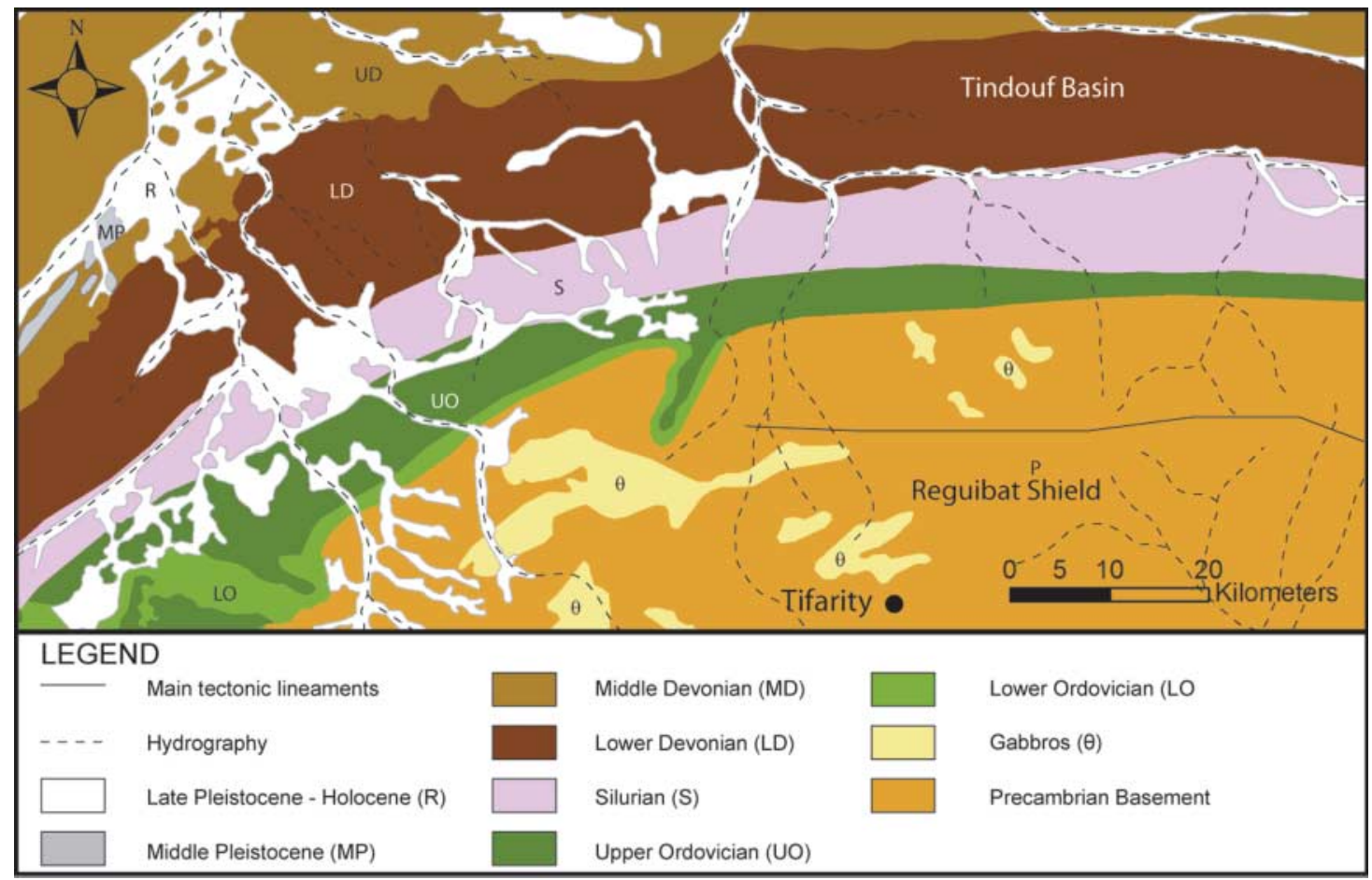

Figure 2. Geological sketch map of the study area (redrawn after Saadi et al., 1985).

study area, located in Western Sahara. This similarity has been confirmed by the geological survey though the identification of the same lithologies cropping out close to Djebilet.

\section{Material and methods: satellite data acquisition and analysis}

In order to discriminate the lithologies cropping out in the study area, a subset of a Landsat 7 ETM+ image, path 203, row 42, acquired in October 2000, was calibrated and enhanced producing color composites using ENVI 4.7. In this simple and basic image processing technique, three bands were selected as the primary colors red, green and blue (RGB) to emphasize the difference among lithologies. According to the lithologies expected to occur in the study area, five principal suitable band combinations (displayed in RGB mode) are mentioned in the literature: 742, 457, 541, 751 and 753 (cf. Daneshfar, Desrochers, \& Budkewitsch, 2006; Dehnavi, Sarikhani, \& Nagaraju, 2010; Deller, 2006; Ramadan \& Kotny, 2004; Qaid \& Basavarajappa, 2008; Zumsprekel \& Prinz, 2000). Decorrelation stretching was used on the most informative color composites formed by highly correlated images, because it allows specific handling of decorrelated data by emphasizing subtle color variations while preserving original data color relationships (Rothery \& Hunt, 1990). Band ratios are generally more useful than single bands to discriminate changes caused by topographic features and illumination conditions of the scene, especially when they are produced by combining three ratio images in the red, green, and blue bands. The most commonly used composites formed by band ratios in RGB have been evaluated: $3 / 5-3 / 1-5 / 7,3 / 1-5 / 7-5 / 4,5 / 7-3 / 1-4 / 3$ and 5/7-4/ 5-3/1 (cf. Aydal, Arda, \& Dumanlilar, 2007; Elsayed Zeinelabdein \& Albiely, 2008; Kaufmann, 1988; Rajesh, 2008; Ramadan \& Kotny, 2004). Principal Component Analysis (PCA) has proved useful for lithologic discrimination among rocks with subtle chemical differences. This technique is generally applied to compress multispectral datasets by calculating a new fictitious coordinate system, thus obtaining new uncorrelated components (Loughlin, 1991) called principal components, which can be used to improve the accuracy of the composites in RGB (Aydal et al., 2007; Ramadan \& Kotny, 2004; Siljestrom, Moreno, Vikgren, \& Caceres, 1997). In detail, the PCA was performed by using the covariance matrix (Table 1), where all the available bands, except the thermal band, are used as input for the calculation. The photo-lithological units obtained through this method were integrated with the 1:1,000,000 geological map (Saadi, Hilali, Bensaid, Boudda, \& Dahmani, 1985) and with the stratigraphic data available in the literature (Guerrak, 1988a). The results were validated through a field campaign performed during April 2011. All the drawing and digitizing activities were completed using Esri ArcGIS 9.3. Ancillary 
Table 1. Eigenvector loadings and variance distribution for the test site sub-scenes.

\begin{tabular}{lllllrrrr}
\hline ETM Band & PC1 & PC2 & PC3 & PC4 & PC5 & PC6 & Mean & $S D$ \\
\hline 1 & -0.16 & -0.21 & 0.07 & -0.62 & -0.41 & 0.62 & 59.43 & 6.67 \\
2 & -0.26 & -0.26 & 0.16 & -0.57 & 0.02 & -0.72 & 61.02 & 10.46 \\
3 & -0.43 & -0.39 & -0.03 & 0.02 & 0.76 & 0.30 & 84.32 & 18.29 \\
4 & -0.53 & -0.43 & -0.07 & 0.51 & -0.51 & -0.08 & 101.46 & 22.47 \\
5 & -0.52 & 0.59 & 0.61 & 0.05 & 0.01 & 0.07 & 145.79 & 24.93 \\
7 & -0.42 & 0.45 & -0.77 & -0.18 & 0.07 & -0.04 & 131.53 & 21.33 \\
Variance & $94.77 \%$ & $3.77 \%$ & $0.84 \%$ & $0.41 \%$ & $0.13 \%$ & $0.08 \%$ & & \\
\hline
\end{tabular}

field data (GPS coordinates, samples, photos) collected during the field survey were also included to establish some reference points.

\section{Results and discussion}

Photo-interpretation of Landsat ETM+ images were performed on a chromatic and textural basis and led to distinguishing 13 'photo-lithological units' (Figure 3), which were tentatively correlated to the lithologic units defined in the literature (Guerrak, 1988a). Two photo-lithological units were named 'Basement', followed by a progressive number (B1-B2), were identified within the Precambrian Shield, whereas nine photo-lithological units, named as 'Tindouf', followed by a progressive number, were identified within the Paleozoic stratigraphic sequence (T1T9). The 'Tindouf' photo-lithological units can be correlated with the Paleozoic sedimentary formations, described by Guerrak (1988a, Figure 4). Furthermore a geological survey was performed to validate both the interpretation of Guerrak (1988a) and the results coming from the remote sensing techniques. The lithologies and the boundaries among them, described by Guerrak (1988a), were recognized in the field and used for the validation of the photo-interpretation analysis. From south to north, the defined photo-lithological units are described as follows:

(a)



(c)

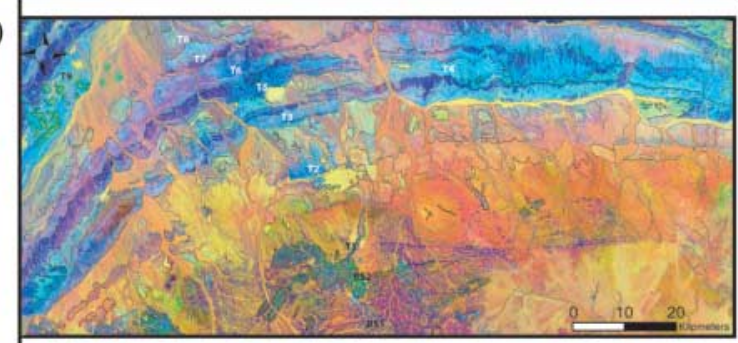

(e)

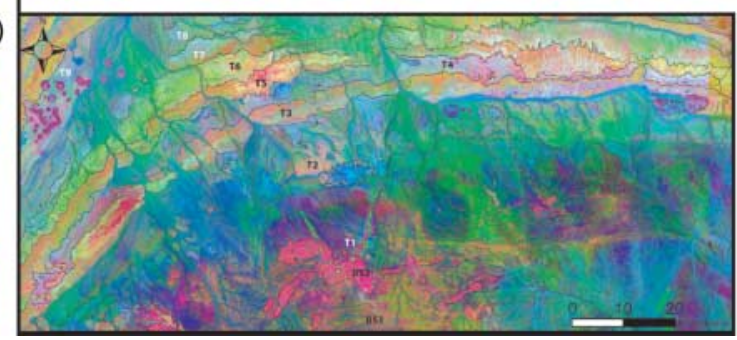

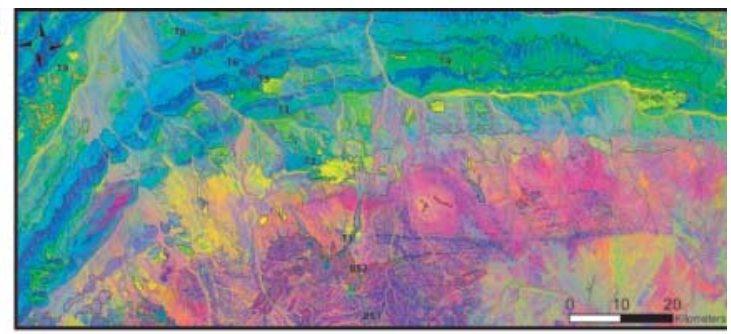

(d)



(f)

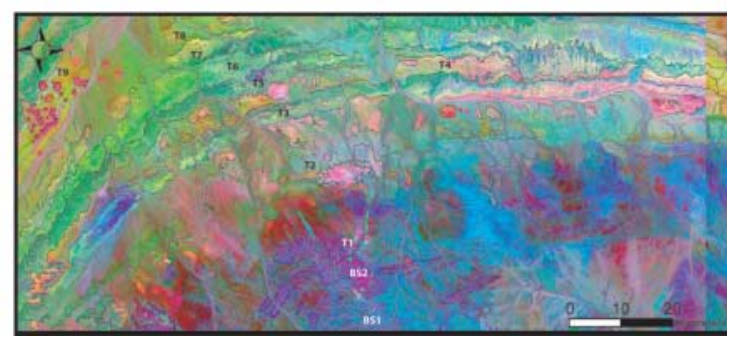

Figure 3. Examples of the enhancements performed on Landsat images. (a) composite 541; (b) composite 457 with decorrelation stretching; (c) composite 3/1 5/7 5/4; (d) composite 5/7 3/1 4/3; (e) composite PC 123; (f) composite PC 324. 


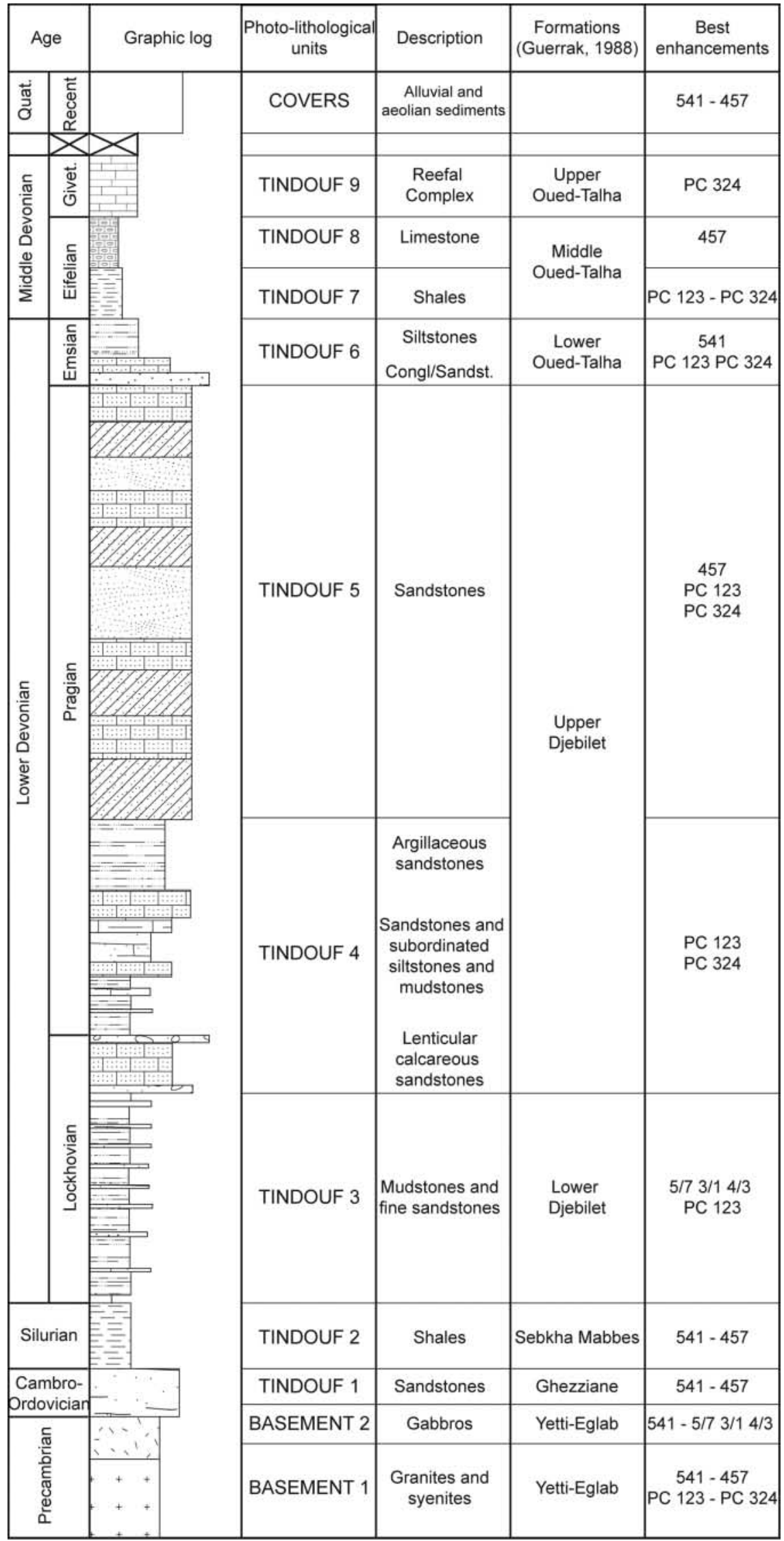

Figure 4. Stratigraphic column of the study area (redrawn after Guerrak, 1988a). 
(1) B1: this unit is widely exposed in the southern part of the study area and appears light green and blue in the 541 composite, pink and purple in the 457 with decorrelation stretching, light-blue in the 5/7, 3/1, 4/ 3 , purple and indigo in the $3 / 1,5 / 7,5 / 4$ composite. Both of the color composites formed using the principal components were very useful in delineating the boundary between the Paleozoic sediments and the Reguibat Shield, which appears green and blue in PC 123 and blue in PC 324. Following the 1:1,000,000 geological maps of Morocco (Saadi et al., 1985) and the ground validation data, this unit was referred to as the Precambrian basement of the Reguibat Shield (West African Craton), which mainly consists of coarse-grained, strongly altered and pervasively fractured quartz-rich in granite and pink syenite (Figure 5).

(2) B2: because of its modest extent relative to the unit B1, it is difficult to detect through medium resolution images. It crops out mainly northwest of Tifarity, within the Reguibat Shield. Partial results were obtained using composite 541 and composite 5/7 3/1 4/3 in RGB, where the unit B2 appears dark green and pink, respectively. Composite 457 with decorrelation stretching and composite 3/1 5/7 5/4 in RGB were not useful in discriminating this unit. PC-derived composites have to be used with caution, because they can overestimate the real extent of the unit. With reference to the 1:1,000,000 geological map of Morocco (Figure 2) (Saadi et al., 1985) and the field observations, it can be correlated to the gabbro intrusive dykes. Gabbros are greatly subordinated with respect to granites and syenites.

(3) T1: stratigraphically this is the lowest of the nine units recognized in the Paleozoic basin filling sequence and it is exposed across the entire width of the study area. This unit is located at the boundary between the Paleozoic sediments and the Reguibat Shield. T1 unit appears light brown in the 541 composite, light blue in the 457 , while it cannot be easily distinguished in the ratio pair composite $3 / 15 / 75 / 4$. Composite $5 / 73 / 14 / 3$ shows a good contrast between this unit and the following T2 unit, allowing the detection of the northern boundary, whereas it does not highlight the limit with the Precambrian basement. On the contrary, the composites formed using PCs are very useful to delineate the southern limit, but not the northern one. This unit mainly consists of layered and fractured quartz-rich sandstone (Figure 6), corresponding to the Ordovician Ghezziane Formation of Guerrak (1988a).

(4) T2: this unit crops out on flat mesas, surrounded by wadis, coming from the Reguibat Shield. At the northern boundary of this unit, the wadis enter several gorges, and there is a consequent reduction of

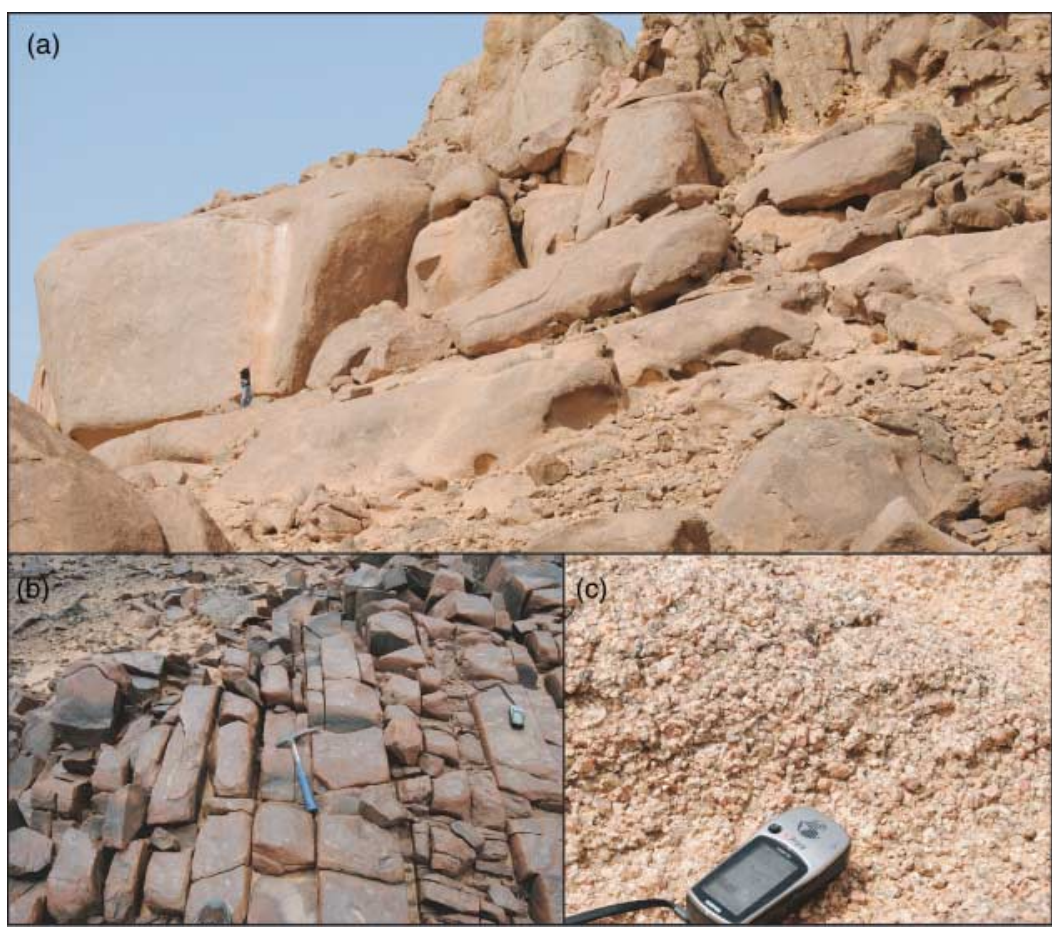

Figure 5. Field pictures of Precambrian basement lithologies. (a) Granites of the Reguibat Shield; (b) Syenites of the Reguibat Shield; (c) detail of picture a). 


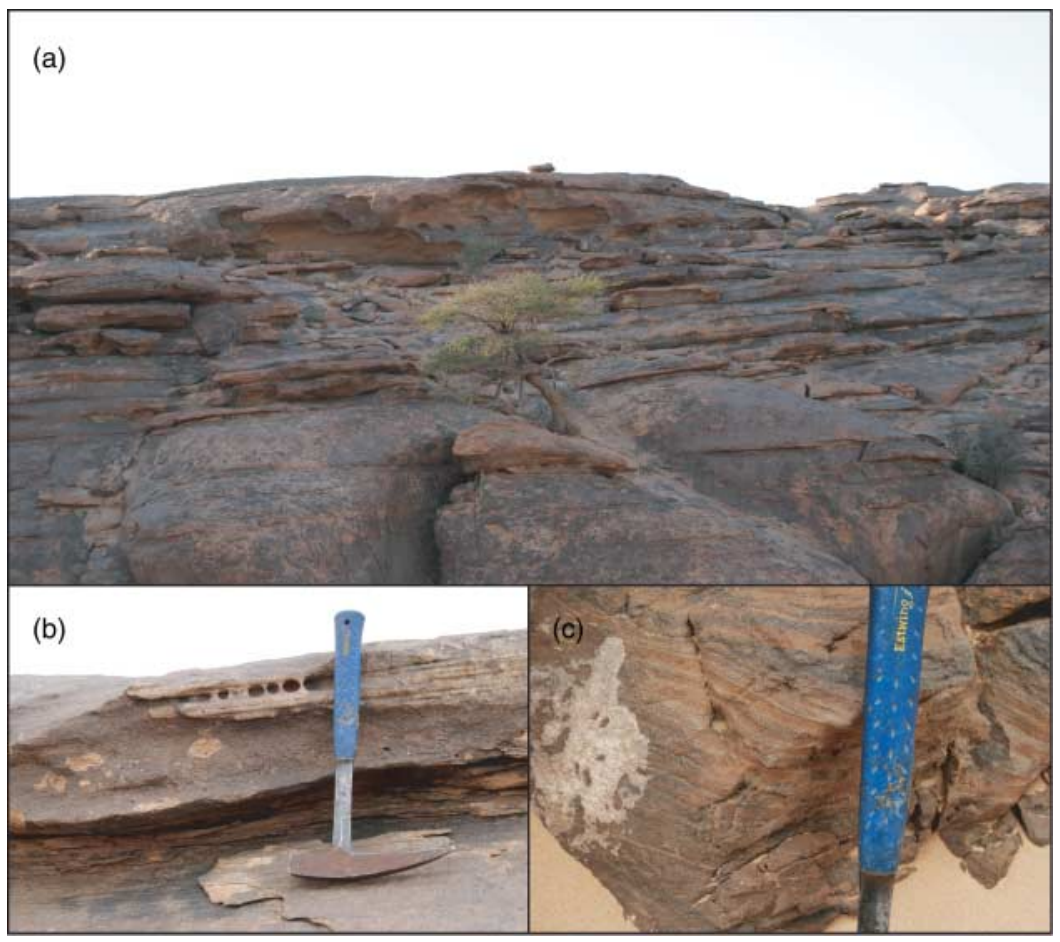

Figure 6. Field pictures of the Ordovician sedimentary succession. (a) Ordovician sandstones; (b) and (c) details of picture a).

the channel width. This geomorphological framework allows the deposition of fluvial and aeolian sediments on the surface of the mesa, shielding the original lithology and causing interference in its reflectance characteristics. Where the recent cover is absent, the unit T2 appears dark brown or purple in the 541 composite. In the 457, it is portrayed in dark blue in the central and eastern part of the study area and in purple in the western part. This divergence could be related to the different orientation of the geological structure, which trends northeast in the western portion of the map area and trends eastward in the eastern half of the map. The composite formed by ratios $3 / 15 / 75 / 4$ does not highlight this unit with a single color, but it is useful in delineating its boundary due to the high contrast with the neighboring units. Ratios 5/7 3/1 4/3 as RGB correlate with the fluvial cover and aeolian sediments, but, where they are missing, T2 is represented in purple. Results from composites obtained through PCs were inconclusive. The T2 unit likely corresponds to the Silurian shales (Guerrak, 1988a).

(5) T3: the lithologies making up this unit to the top of the sequence are spectrally very similar because they consist mainly of interlayered mudstone, limestone, sandstone and siltstone. Most simple image enhancements, such as the 541 color composite, use highly correlated spectral bands, which are not very useful to delineate differences between lithologies having similar physical or spectral features. Regardless, this unit appears as several shades of brown in the 541 composite, similar to T4 to the north. Thus, the 541 composite is not useful to delineate the northern boundary of T3, but it can be used for the southern boundary because of the contrast in the RGB image between the lithologies at the base of T3 and the Silurian shale at the top of T2. Specifically, the basal level of limestone is highlighted in red in the 541 composite and it is observed throughout the study area. The 457 composite shows better results than the 451 composite in delineating the extent of T3, which appears in blue with the exception of the limestone level which is colored green. This is probably caused by increased decorrelation between spectral bands. Among the band ratios composites, the 5/7 3/1 4/3 was the most useful, because it was able to delineate both the upper and lower boundaries of T3. The best enhancement for this unit is represented by the PC 123 as a RGB image, where the unit T3 is orange and characterized by a high contrast relative to $\mathrm{T} 2$ and $\mathrm{T} 4$. T3 probably corresponds to the Lochkovian limestone (Figure 7) and the interlayered mudstone and fine-grained sandstone of the Djebilet Formation as defined by Guerrak (1988a). 


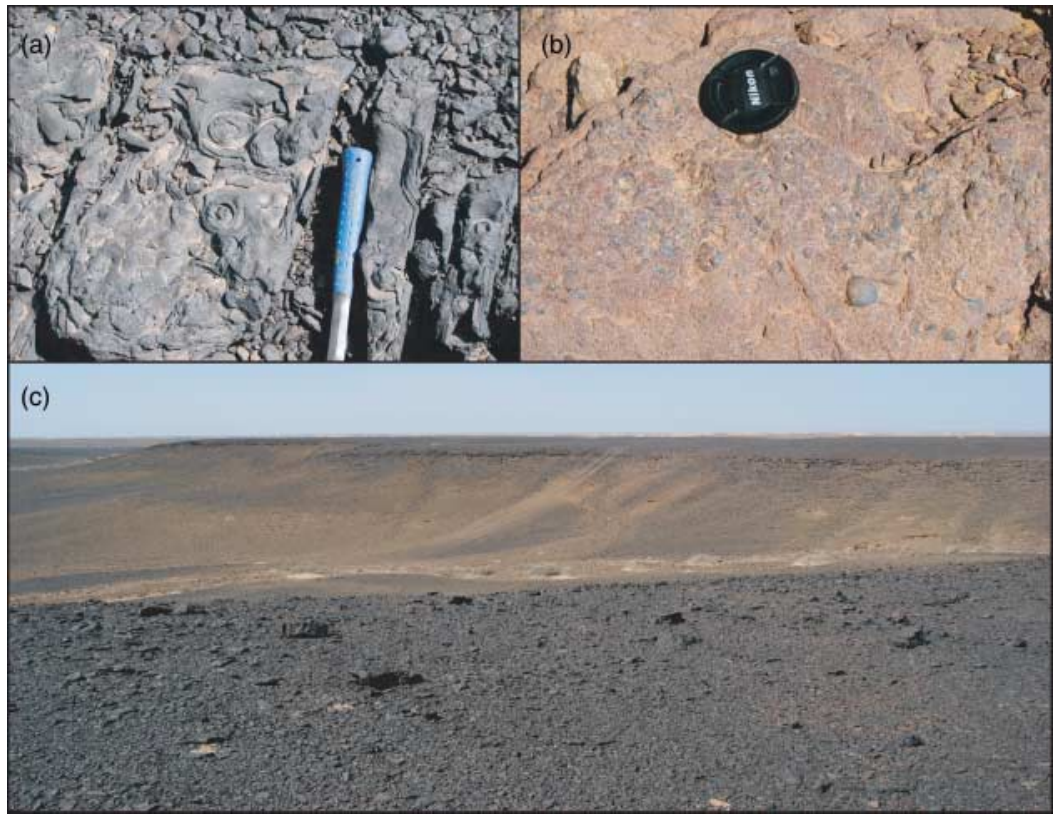

Figure 7. Field pictures of the Devonian sedimentary succession. (a) Detail of the Pragian sandstones of the Tindouf 5 unit; (b) Detail of the fossiliferous limestone at the base of the Tindouf 3 unit; (c) Landscape of the Pragian sandstones of the Tindouf 5 unit.

(6) T4: this unit is affected by similar issues found in T2. It crops out at the top of a mesa that is bounded by two cuestas. In this area, the river beds of the wadis widen again, and the main drainage direction of the rivers is westward, which differs from the drainage direction in T3 and T5 where the rivers flow north and northwest. This framework favors fluvial deposition because the river beds are located on gently dipping surfaces bounded by the scarp of the cuestas. Fluvial deposits therefore interfere with the spectral response of the bedrock lithologies. T4 appears purple in the 541 composite, and fluvial cover deposits are light brown. Composites 457,3/1 5/7 5/4 and 5/7 3/1 4/3 did not result in any useful map interpretations; they appear as various colors, sometimes similar to the colors characterizing T3 and T5. Both the composites formed by PCs as RGB were very useful. Although they highlight this unit with a variety of colors, they allow an accurate mapping of the northern boundary with $\mathrm{T} 3$ and the southern boundary with T5. Compared with the available data (Guerrak, 1988a; Saadi et al., 1985), T4 is correlated with the Lochkovian calcareous sandstone and the lower part of the Pragian consisting of interlayered mudstone, siltstone and fine-grained sandstone.

(7) T5: in the 541 composite, T5 appears dark brown with minor occurrences of red. The 457 composite is depicted dark blue and is very helpful in delineating the extent of T5. The same applies to the 3/1 5/7 5/4 composite. Composite 5/7 3/1 4/3 was less useful because it does not highlight the contrast between T5 and the T4 and T6 units. Similar to T4, composites formed using PCs are very useful. PC 123 highlights T5 as orange and PC 324 as dark green. T5 might be correlated with Pragian sandstones (Figure 7) of the Djebilet Formation (Guerrak, 1988a). This unit can easily be recognized, because it is formed by sandstones very rich in iron minerals, which affect the spectral behavior of the host lithology, especially when using $3 / 1$ and $5 / 4$ ratios. These last ratio are very useful because they highlight the presence of iron minerals (Ciampalini, Garfagnoli, Antonielli, Moretti, \& Righini, 2012).

(8) T6: T6 appears light brown and light red in the 541 composite, which was very useful in separating this unit from both T5 and T7. In composite 457, T6 appears light blue contrasting with the dark blue or green of the adjacent units. A very similar result can be obtained using composite 3/1 5/7 5/4. The 5/7 3/1 4/ 3 composite is less informative, but it can be used in the western part of the study area to delineate the southern limit of the unit. More information can be obtained using the PCs where T6 appears as light green, and both the southern and northern boundaries can be followed throughout the study area. This 
unit was interpreted as the Lower Oued Talha Formation (Emsian) composed of conglomerate, sandstone and subordinately siltstone.

(9) T7: in the 541 composite T7 appears as different shades of brown and it is easily delineable in the eastern part of the study area; however, in the southwestern part of the map it can be indistinguishable from the neighboring photo-lithological units, probably because of the presence of widespread aeolian deposits, fluvial cover or both. Unit T7 is observed as dark blue using the 457 composite and the $3 / 15 / 75 / 4$ image. The $5 / 73 / 14 / 3$ composite can be used only in the eastern part for delineating the southern boundary. More accurate information can be obtained from the composites formed using PCs. In particular, PC 324 highlights this unit in orange contrasting with the green of T6 and T8. From the published maps and literature (Guerrak, 1988a), this unit is correlated with the middle Oued Talha Formation (Emisian-Givetian), predominantly consisting of shale.

(10) T8: this unit is mostly characterized by being covered by the deposits of the largest wadi in the map area. Its lower contact was defined using enhanced images, whereas the upper boundary was interpreted because the reef mounds (Givetian) outcropping nearby pertain to the T9 unit. It appears light brown in the 541 composite, green and blue in the 457 , light blue in the $3 / 15 / 75 / 4$, and as assorted colors in the $5 / 73 / 14 / 3$ composites, but these enhancements do not show consistent differences from $\mathrm{T} 7$. Both the composites formed using the principal components were not informative. The T8 unit is considered part of the middle Oued Talha Formation (Eifelian; Guerrak, 1988a) and consists of limestone.

(11) T9: in the 541 composite image, this unit is purple and subordinately dark brown, whereas the reef mounds are noticeably blue. Using composites 457 and 3/1 5/7 5/4, T9 is characterized by a blue color, and the reefs appear orange in the former case and green in the latter. The $5 / 73 / 14 / 3$ composite is influenced by the presence of fluvial and aeolian cover, but the reefs are detectable in fuchsia. PC 123 is the least informative composite, but it can be used for mapping the reefs, which appear purple. The most interesting composite is PC 324, which highlights T9 in green and the reefs in fuchsia, allowing the mapping of the lower boundary of this unit. In the photo-lithological map, the reefs were distinguished from the rest of the sedimentary succession, as they are particularly well recognizable by shape and color. This unit crops out in the northwestern most part of the study area, but the boundary with T8 is partly

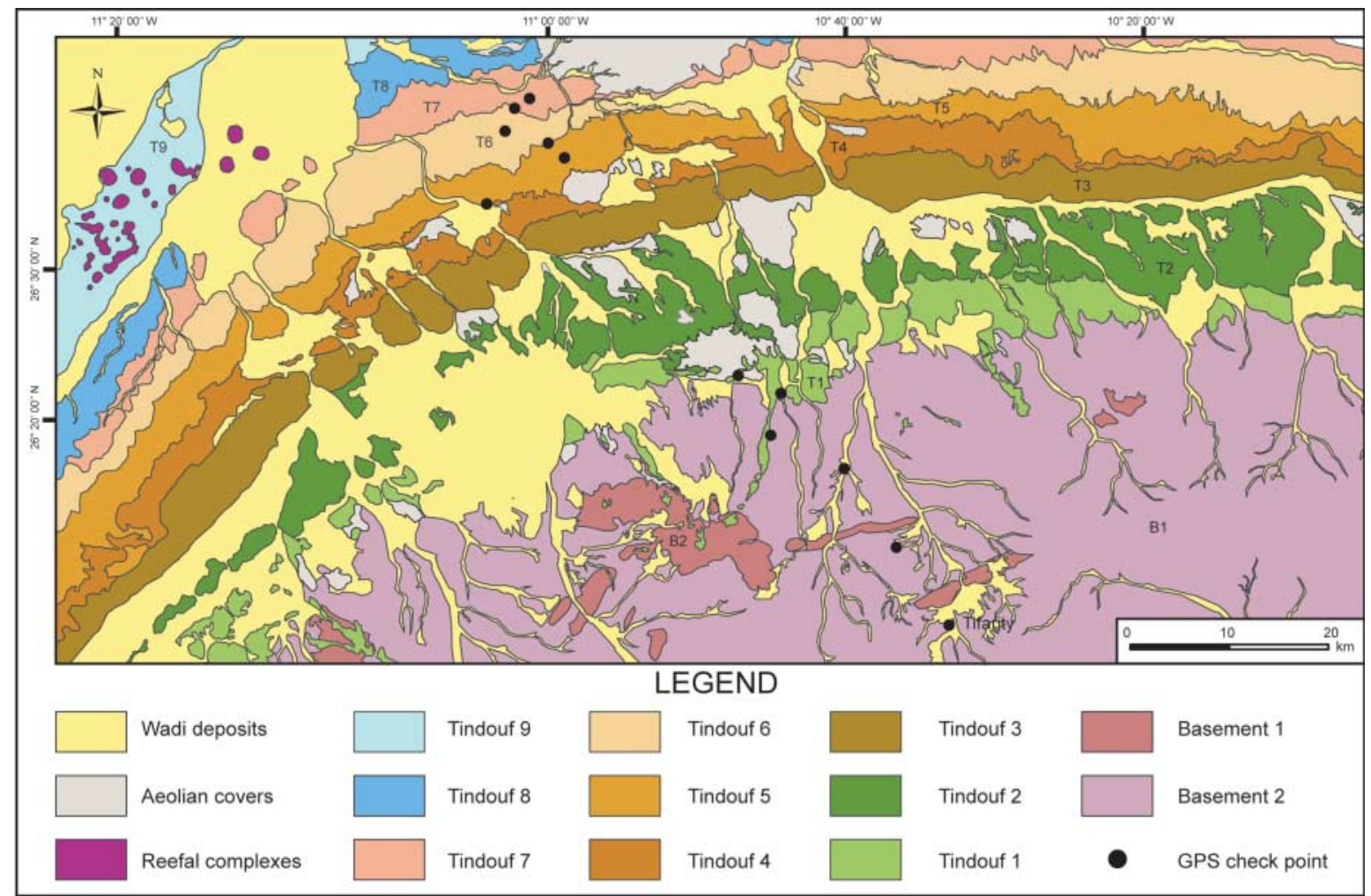

Figure 8. Photo-lithological map drawn from Landsat ETM+ images. 
covered by fluvial deposits. T9 is stratigraphically the highest unit of the nine distinguished in the Paleozoic Tindouf Basin. It includes Givetian (in age) reef complexes of various sizes and is made up of sandstones and siltstones (Schindler \& Wehrmann, 2010). It is correlated with the Oued Talha Formation of Guerrak (1988a). T9 is correlated with the upper Oued Talha Formation (Givetian), consisting of siliciclastic siltstone and sandstone and carbonates at the top of the mounds (Guerrak, 1988a; Schindler \& Wehrmann, 2010).

(12) Cover: this unit is white in the 541 composite, yellow in composite 457 with decorrelation stretching, light blue and yellow in the $3 / 1,5 / 7,5 / 4$, and fuchsia and yellow in the $5 / 7,5 / 4,3 / 1$ composite. Composites formed using PCs were unusable, because they highlight cover with several different colors. This unit is formed by recent slope or Cenozoic aeolian deposits, predominantly consisting of sand derived from the weathering and disintegration of the granitic Precambrian basement.

(13) Wadi: this unit corresponds to fluvial and alluvial deposits within completely dry riverbeds, occasionally hosting rainwater flow. They mostly consist of loose sandy and silty sediments. The identification of the wadi riverbeds and of the related sediments can be easily performed using single bands or a simple ratio in gray scale. In the study area, the calibrated ETM + band 3 and the band 3/band 1 ratio were very effective at delineating the hydrographic network and its sediments, which appear white or light grey, in contrast with the dark grey and black of bedrock outcrops. More elaborated enhancements can be strongly affected by mineralogical changes in the composition of the river sediments, particularly at the confluence of two or more wadis and highlighted by a color change in deposits along the same wadi.

The 13 recognized 'photo-lithological units' (Figure 8) using the described image processing techniques were used to draw a photo-lithological map of the study area.

\section{Conclusions}

In areas difficult to reach and subject to socio-political and logistical constraints, such as Western Sahara, geological mapping raises a number of issues regarding cost, feasibility and security. In such cases, the use of Landsat 7 ETM+ can provide a particularly effective and low-cost tool for rapid mapping, thanks to the synoptic view and to the capability to distinguish the different lithologies based on their spectral features. In this paper, some enhancement techniques were applied to a Landsat 7 ETM+ subset of the Tindouf basin (Western Sahara), in order to discriminate and map the lithologies. False color composite images, color composites derived from band ratioing or principal component analysis have been particularly effective for the identification of a number of photo-lithological units within the study area, using simple visual recognition. Even though visual interpretation is subjective, it has proved highly valuable for geological mapping, making it possible to map lithologic units with much more detail, with respect to the existing literature (Guerrak, 1988a; Saadi et al., 1985). The integration of pre-existing geological data and data collected during the field survey performed in April 2011, with the analyzed satellite images in a GIS environment, allowed the reliable linking of the photo-lithological units with the available litho-stratigraphic scheme (Guerrak, 1988a) and existing maps (Saadi et al., 1985) for the study area. In particular, the Proterozoic granitic basement and the sedimentary succession of the Tindouf Basin were mapped as 13 photo-lithological units, including alluvial and aeolian deposits. This study demonstrates that, if properly post-processed, minimally expensive optical satellite imagery can represent a valuable tool for rapid and reliable geologic mapping at a regional scale. This method is particularly useful in arid environments due to the absence of widespread vegetation cover. The photo-interpreted maps will be useful guides to ground surveys for a more detailed characterization of the mapped units and of their structural relationships, or to serve as a starting point for mineral resources investigations.

\section{Acknowledgements}

This research was financed by Autostrade per L'Italia S.p.a. The authors gratefully acknowledge the staff of the NGO Ban Slout Larbi and in particular Fiorella Bendoni, as well as the Government of the SADR, particularly of Abdullahi Mohamed Salem, for their invaluable support during the field work. The authors would like to thank to Stuart Gill and an anonymous reviewer for their helpful suggestions which improved the manuscript.

\section{References}

Allek, K., \& Hamoudi, M. (2008). Regional-scale aeromagnetic survey of the south-west of Algeria: A tool for area selection for diamond exploration. Journal of African Earth Sciences, 50, 6778. 
Aydal, D., Arda, E., \& Dumanlilar, O. (2007). Application of the Crosta technique for alteration mapping of granitoidic rocks using ETM+ data: Case study from eastern Tauride belt (SE Turkey). International Journal of Remote Sensing, 28, $3895-3913$.

Baghdadi, N., Grandjean, G., Lahondére, D., Paillou, P., \& Lasne, Y. (2005). Apport de l'imagerie satellitaire radar pour l'exploration géologique en zones arides. The contribution of radar satellite imagery to geological exploration in arid areas. C.R. Geoscience, 337, 719-728.

Barth, M.G., Rudnick, R.L, Carlson, R.W., Horn, I., \& McDonough, W.F. (2002). Re_/Os and U_/Pb geochronological constraints on the eclogite/tonalite connection in the Archean Man Shield, West Africa. Precambrian Research, 118, $267-283$.

Ciampalini, A., Garfagnoli, F., Antonielli, B., Moretti, S., \& Righini, G. (2012). Remote sensing techniques using Landsat ETM+ applied to the detection of iron ore deposits in Western Africa. Arabian Journal of Geosciences, doi: 10.1007/ s12517-012-0725-0.

Daneshfar, B., Desrochers, A., \& Budkewitsch, P. (2006). Mineral-potential mapping for MVT deposits with limited data sets using Landsat data and geological evidence in the Borden Basin, Northern Baffin Island, Nunavut, Canada. Natural Resources Research, 15, 129-149.

Dawelbait, M., \& Morari, F. (2011). Limits and potentialities of studying dryland vegetation using the optical remote sensing. Italian Journal of Agronomy, 3, 97-106.

Dehnavi, A.G., Sarikhani, R., \& Nagaraju, D. (2010). Image processing and analysis of mapping alteration zones in environmental research, East of Kurdistan, Iran. World Applied Sciences Journal, 11, 278-283.

Deller, M.E. (2006). Facies discrimination in laterites using Landsat Thematic Mapper, ASTER and ALI data - examples from Eritrea and Arabia. International Journal of Remote Sensing, 27, 2389-2409.

Destombes, J., Hollard, H., \& Willefert, S. (1985). Lower Palaeozoic rocks of Morocco. In C.H. Holland (Ed.), Lower Palaeozoic of North-western and West Central Africa (pp. 91-336). New York: John Wiley.

Deynoux, M., Affato, P., Trompette, R., \& Villeneuve, M. (2006). Pan-African tectonic evolution and glacial events registered in Neoproterozoic to Cambrian cratonic and foreland basins of West Africa. Journal of African Earth Sciences, 46, $397-426$.

Dogan, H.M. (2008). Applications of remote sensing and Geographic Information Systems to assess ferrous minerals and iron oxide of Tokat province in Turkey. International Journal of Remote Sensing, 29, 221-233.

Dogan, H.M. (2009). Mineral composite assessment of Kelkit River Basin in Turkey by means of remote sensing. Journal of Earth System Science, 118, 701-710.

Elsayed Zeinelabdein, K.A., \& Albiely, A.I. (2008). Ratio image processing techniques: A prospecting tool for mineral deposits, Red Sea Hills, NE Sudan. The International Archives of the Photogrammetry, Remote Sensing and Spatial Information Sciences, 37(B8), 1295-1297.

Gad, S., \& Kusky, T.M. (2006). Lithological mapping in the Eastern Desert of Egypt, the Barramiya area, using Landsat thematic mapper (TM). Journal of African Earth Sciences, 44, 196-202.

Ghienne, J.F. (2003). Late Ordovician sedimentary environments, glacial cycles, and post-glacial transgression in the Taoudeni Basin, West Africa. Palaeogeography, Palaeoclimatology, Palaeoecology, 189, 117-145.

Guerrak, S. (1988a). Geology of Early Devonian oolitic iron-ore of the Gara Djebilet field, Sahara Platform, Algeria. Ore Geology Reviews, 3, 333-358.

Guerrak, S. (1988b). Ordovician ironstone sedimentation in Ougarta Ranges: North Western Sahara (Algeria). Journal of African Earth Sciences, 7, 657-678.

Guerrak, S. (1991). Paleozoic patterns of oolitic ironstone sedimentation in the Sahara. Journal of African Earth Sciences, 12 , 31-39.

Gupta, R.P. (2003). Remote sensing geology. Berlin: Springer.

Kaufmann, H. (1988). Mineral exploration along the Aqaba-Levant Structure by use of TM-data: Concepts, processing and results. International Journal of Remote Sensing, 9, 1639-1658.

Le Heron, D.P. (2007). Late Ordovician glacial record of the Anti-Atlas, Morocco. Sedimentary Geology, 201, $93-110$.

Loi, A., Ghienne, J.F., Dabard, M.P., Paris, F., Botquelen, A., Christ, N., \& . . Destombes, J. (2010). The Late Ordovician glacio-eustatic record from a high-latitude storm-dominated shelf succession: The Bou Ingarf section (Anti-Atlas, Southern Morocco). Palaeogeography, Palaeoclimatology, Palaeoecology, 296, 332-358.

Loughlin, W.P. (1991). Principal component analysis for alteration mapping. Photogrammetric Engineering \& Remote Sensing, $57,1163-1169$.

Lubeseder, S., Redfern, J., \& Boutib, L. (2009). Mixed siliciclastic-carbonate shelf sedimentation-Lower Devonian sequences of the SW Anti-Atlas, Morocco. Sedimentary Geology, 215, 13-32.

Madani, A.A. (2009). Utilization of Landsat ETM+ data for mapping gossans and iron rich zones exposed at Bahrah area, Western Arabian Shield, Saudi Arabia. Journal of King Abdulaziz University: Earth Sciences, 20, 25-49.

Peucat, J.J., Capdevila, R., Drareni, A., Mahdjoub, Y., \& Kahoui, M. (2005). The Eglab massif in the West African Craton (Algeria), an original segment of the Eburnean orogenic belt: Petrology, geochemistry and geochronology. Precambrian Research, 136, 309-352.

Qaid, A.M., \& Basavarajappa, H.T. (2008). Application of optimum index factor technique to Landsat-7 data for geological mapping of North East of Hajjah, Yemen. American-Eurasian Journal of Scientific Research, 3, 84-91.

Rajesh, H.M. (2008). Mapping proterozoic unconformity-related uranium deposits in the Rockhole area, Northern Territory, Australia using Landsat ETM+. Ore Geology Reviews, 33, 382-396.

Ramadan, T.M., \& Kotny, A. (2004). Mineralogical and structural characterization of alteration zones detected by orbital remote sensing at Shalatein District, SE Desert, Egypt. Journal of African Earth Sciences, 40, 89-99. 
Rothery, D.A., \& Hunt, G.A. (1990). A simple way to perform decorrelation stretching and related techniques on menu-driven image processing systems. International Journal of Remote Sensing, 11, 133-137.

Saadi, M., Hilali, E.A., Bensaïd, M., Boudda, A., \& Dahmani, M. (1985). Carte Géologique du Maroc, echelle 1/1000000. Geological map of Morocco, scale 1:1000000. Edition du Service Géologique du Maroc, Notes et Mémoires n 260

Sabins, F. (1999). Remote sensing for mineral exploration. Ore Geology Reviews, 14, 157-183.

Schindler, E., \& Wehrmann, A. (2010). Genesis and internal architecture of the Middle to Upper Devonian Gwirat Al Hyssan reef-mound (Western Sahara). Palaeogeography, Palaeoclimatology, Palaeoecology, 304, 184-193.

Shalaby, M.H., Bishta, A.Z., Roz, M.E., \& Zalaky, M.A. (2010). Integration of geologic and remote sensing studies for the discovery of uranium mineralization in some granite plutons, Eastern Desert, Egypt. Journal of King Abdulaziz University: Earth Sciences, 21, 1-25.

Siljestrom, P.A., Moreno, A., Vikgren, K., \& Caceres, L.M. (1997). Technical note: The application of selective principal component analysis (SPCA) to Thematic Mapper (TM) image for the recognition of geomorphologic features configuration. International Journal of Remote Sensing, 18, 3843-3852.

Villeneuve, M. (2005). Paleozoic basins in West Africa and the Mauritanide thrust belt. Journal of African Earth Sciences, 43 , $166-195$.

Wulder, M.A., White, J.C., Goward, S.N., Masek, J.G., Irons, J.R., Herold, M., \& .. Woodcock, C.E. (2008). Landsat continuity: Issues and opportunities for land cover monitoring. Remote Sensing of Environment, 112, 955-969.

Zumsprekel, H., \& Prinz, T. (2000). Computer-enhanced multispectral remote sensing data: A useful tool for the geological mapping of Archean terrains in (semi)arid environments. Computer \& Geosciences, 26, 87-100. 